\title{
A Collaboration of Assertive Training and Physical Activities to Develop Assertive Behaviour in Students with Deafness
}

\author{
Linggi Andiri* \\ Pendidikan Jasmani Kesehatan dan Rekreasi \\ Sekolah Tinggi Keguruan dan Ilmu Pendidikan Pasundan \\ Cimahi, Indonesia \\ *linggi.andiri@gmail.com
}

\author{
Berliana Berliana, Yudy Hendrayana \\ Program Studi Pendidikan Olahraga, Sekolah Pascasarjana \\ Universitas Pendidikan Indonesia \\ Bandung, Indonesia \\ berliana.rahely@yahoo.co.id
}

\begin{abstract}
The purpose of this study was to obtain an overview of the development of Assertive behavior of deaf students through collaborative learning in Assertive Training and Physical Activity. The method used is an experimental method with the design of The Randomized Pretest-Posttest Control Group Design. The sample of this study was all deaf students at the Citeureup Special School in Cimahi which consists of 24 students (14 males and 10 females). Data obtained from the results of the pretest and posttest by using an assertive behavior questionnaire. The data obtained was processed using T-Paired test. The results showed that the experimental group and the control group had a significant effect on the development of assertive behavior in deaf students. The effect of collaborative learning on Assertive Training and Physical Activity of experimental group is greater than the control group, so that the more frequent collaboration learning is carried out, the more assertive behavior of deaf students is developed.
\end{abstract}

Keywords-collaboration; assertive training; physical activity; asertif; deafness

\section{INTRODUCTION}

A deaf student is playing basketball on the field. Suddenly the ball is forcibly grabbed by another person and the deaf student is only quietly resigned to the condition. There was no attempt to refuse or ban the ball from being taken, even though at that time the deaf student was eager to play basketball.

The conditions experienced by the deaf student show that it is difficult to say "no" to something that is not pleasing to him (not assertive), always plagued by fear of facing those around him [1]. In fact, every person in society including the deaf student is free to have the rights as an individual. One of these rights is to decide what is best for themselves, including saying "no" to something unpleasant.

To be able to realize this right, individuals must learn to define their position or defend their beliefs when interacting with those who can control them [2]. But in fact it is difficult for the deaf student to realize his rights. Deafness, however, can significantly influence his oral and hearing expression, as well as in the learning process and social interaction [3]. Suarez's research shows that deaf children are less able to empathize, social perception, solve social problems, and some other social aspects [4].

An effort to help overcoming this problem is to provide Assertive Training in collaboration with physical activity. The main purpose of Assertive Training is to help people in finding the realization of their irreversible personal rights [5]. Furthermore, participating in physical activity and exercise is one way to improve one's assertive behavior [6], participation in physical activity and exercise encourages young people with disabilities to develop their skills, performance, and psychosocial competencies [7], reduce stress, improve selfesteem, confidence, and assertive behavior [8-10].

The studies that have been conducted show that physical activity has a positive impact on developing one's assertive behavior. However, from several studies that have been conducted, there is no research that discusses Assertiveness with physical activity in people who have special needs. While the literature shows that variables such as education, experience, work, age, health, and past assertive training can affect one's assertive level [11]. The absence of assertive research on people with special needs who in fact have problems in health attracted the interest of writers to be able to fill the vacancy into a further study. Yigiter recommends that further research should be carried out using physical programs that differ in their intensity, duration and type [12].

This study tries to collaborate between Assertive training and Physical Activity, namely physical activity which is programmed, then developed and strengthened through Assertive Training which is an additional dimension where Assertive is directly emphasized in physical activity. Besides, there is Assertive reinforcement during core activities and cooling, whose purpose is to help educators incorporate Assertive Training into physical education curriculum [1].

\section{METHOD}

\section{A. Participant}

The sample in the study was deaf students at the Citeureup Special School (SLB) in Cimahi which numbered 24 students, consisting of 10 female students and 14 male students. The 
sampling technique in this study was Total Population Sampling [13].

\section{B. Procedures}

This type of research is True Experimental with Randomized Pretest Post-Test Control Design [14]. The number of treatments is 8 meetings based on the Assertive
Training program according to Avarars and Alkaya [15]. The research program is as follows:

TABLE I. RESEARCH PROGRAM

\begin{tabular}{|l|l|l|l|}
\hline \multicolumn{1}{|c|}{ Session (S) } & \multicolumn{1}{|c|}{ Assertive Training Program } & \multicolumn{1}{c|}{ Problem Condition } & \multicolumn{1}{c|}{ Physical Activity Program } \\
\hline Session 1 & Exercise for self-expressing & Unreasonable Request & Big ball game \\
\hline Session 2 & Exercise to respect for others & Conflict & Big ball game \\
\hline Session 3 & Express feelings explicitly & Agresif People & Big ball game \\
\hline Session 4 & Exercise for being honest about the condition & Mistake & Big ball game \\
\hline Session 5 & Exercise for managing anger & Conflict, Agresif People & Big ball game \\
\hline Session 6 & Exercise for being calm & Criticism, Mistake & Big ball game \\
\hline Session 7 & Exercise to refuse and be brave to say 'no' & Conflict, Unreasonable Request & Big ball game \\
\hline Session 8 & Exercise for communicating & Criticism, Mistake & Big ball game \\
\hline
\end{tabular}

\section{Instrument}

The instrument used in this study is an assertive behavior questionnaire, which is an instrument used to measure a person's assertive behavior which is compiled based on assertive behavioral indicators. The instrument contains 80 statements. Data processing is performed by the T-Paired Test on SPSS 21.

\section{RESUlTS AND DISCUSSION}

\section{A. Data Description}

TABLE II.

DATA DESCRIPTION OF ASSERTIVE BEHAVIOUR

\begin{tabular}{|l|l|l|l|l|}
\hline & \multicolumn{1}{|c|}{ N } & \multicolumn{1}{c|}{ Sum } & \multicolumn{1}{c|}{ Mean } & \multicolumn{1}{c|}{ Std. Deviation } \\
\hline Pretest.ex & 12 & 968 & 80.67 & 11.919 \\
\hline Posttest.ex & 12 & 1011 & 84.25 & 14.605 \\
\hline Pretest.con & 12 & 971 & 80.92 & 12.280 \\
\hline Posttest.con & 12 & 992 & 82.67 & 13.727 \\
\hline Valid N (listwise) & 12 & & & \\
\hline
\end{tabular}

From the description of the data in Table 2, the posttest score of Assertive behavior in deaf students given Collaborative Assertive Training and Physical Activity learning was 84.25 while the posttest mean score of Assertive behavior in deaf students who were given Physical Activity learning without Assertive Training was 82.67. That means, judging from the average posttest, that Collaboration on Learning Assertive Training and Physical Activity is more influential in improving Assertive behavior of deaf students at Citeureup Special School.

The difference in the effect of learning collaboration on Assertive Training and Physical Activity with Physical Activity without Assertive Training.

TABLE III. T-PAIRED TEST OF EXPERIMENTAL GROUP

\begin{tabular}{|c|c|c|c|c|c|c|c|c|c|}
\hline \multicolumn{10}{|c|}{ Paired Samples Test } \\
\hline & & \multicolumn{5}{|c|}{ Paired Differences } & \multirow{3}{*}{$t$} & \multirow{3}{*}{$d f$} & \multirow{3}{*}{ Sig. (2-tailed) } \\
\hline & & \multirow[t]{2}{*}{ Mean } & \multirow{2}{*}{$\begin{array}{c}\text { Std. } \\
\text { Deviation }\end{array}$} & \multirow{2}{*}{$\begin{array}{l}\text { Std. Error } \\
\text { Mean }\end{array}$} & \multicolumn{2}{|c|}{\begin{tabular}{|c|}
$95 \%$ Confidence Interval of \\
the Difference
\end{tabular}} & & & \\
\hline & & & & & Lower & Upper & & & \\
\hline Pair 1 & $\begin{array}{l}\text { Pretest.ex } \\
\text { Posttest.ex }\end{array}$ & -3.583 & 3.118 & 900 & -5.564 & -1.602 & -3.982 & 11 & 002 \\
\hline
\end{tabular}

TABLE IV. T-PAIRED TEST OF CONTROL GROUP

\begin{tabular}{|c|c|c|c|c|c|c|c|c|c|}
\hline \multicolumn{10}{|c|}{ Paired Samples Test } \\
\hline & & \multicolumn{5}{|c|}{ Paired Differences } & \multirow{3}{*}{$\mathbf{t}$} & \multirow{3}{*}{ df } & \multirow{3}{*}{ Sig. (2-tailed). } \\
\hline & & \multirow[t]{2}{*}{ Mean } & \multirow[t]{2}{*}{ Std. Deviation } & \multirow[t]{2}{*}{$\begin{array}{c}\text { Std. Error } \\
\text { Mean }\end{array}$} & \multicolumn{2}{|c|}{$\begin{array}{l}\text { 95\% Confidence } \\
\text { Interval of the } \\
\text { Difference }\end{array}$} & & & \\
\hline & & & & & Lower & Upper & & & \\
\hline Pair 1 & \begin{tabular}{|l|} 
Pretest.con \\
Posttest.con
\end{tabular} & -1.750 & 1.658 & .479 & -2.804 & -.696 & -3.656 & 11 & .004 \\
\hline
\end{tabular}


The testing criterion is if the significance value (2-tailed) $<0.05$, then Ho is rejected. Meanwhile, if the significance value (2-tailed) $>0.05$, then Ho is accepted. Based on table 3 above, the significance value of the experimental group, namely the learning collaboration of Assertive Training and Physical Activity is 0.002 so that Ho is rejected. Thus H1 is accepted, which can be concluded that there is a significant effect of collaborative learning in Assertive Training and Physical Activity in developing assertive behavior in deaf students. Where there are significant differences in the pretest and posttest scores.

Based on table 4 above, the significance value of the control group namely learning Physical Activity without Assertive Training is 0.004 so that Ho is rejected. Thus H1 is accepted, that can be concluded that there is a significant effect of the development of Physical Activity in developing assertive behavior of deaf students. Where there are significant differences in the pretest and posttest scores.

Physical activity in sports education is a fairly complex dimension that might not be obtained in other fields. Compared to the environment that tends to be regular in other classes, children who are involved in sports education classes will: interact a lot, have opportunities to cooperate, arise seeds of conflict, get support from each other, or maybe even get hurt. In short, sports education classes reflect life and can act as a laboratory to learn to live more productively with others [2].

The different effect that occurs between physical activity collaborated with Assertive Training and physical activity without Assertive Training is because in strengthening collaborative learning on Assertive behavior, it is continuously instilled and trained, so students will get used to it. Collaboration on assertive training and physical activity teaches children to talk when they want something. Does he want more playing time? So let him talk to the teacher. When he wants something or has an opinion, encourage him to express it. Students are instructed, directed and trained to be able to express themselves and be able to convey feelings that are felt explicitly through physical activity.

Meanwhile, in learning physical activity without Assertive Training there is no special emphasis on assertive behavior, only refers to natural conditions without specific direction towards assertive behavior. Staniford called for a new focus on sports education where "... children learn about themselves, their environment and how to live in harmony with others." Stanifors explained that these goals cannot be achieved simply by providing a series of activities, games, and sports [2]. Participation in sports and championships can result in firmness if the trainer or authorities emphasize assertive skills and teach them [16]. The differences that occur in this study seem to be still quite small because the amount of treatment carried out is still small. It was found that training conducted in less than six training sessions did not have a significant effect on increased assertiveness [17].

This research supports theories and previous studies that have been carried out such as the research by Boket et. al. which says that skills for assertive behavior can be obtained by
Assertive Training [18]. In addition, the Assertive Training Program aims to help individuals change their self-image, easily express themselves, express their thoughts and ideas appropriately and consequently increase their self-esteem [19]. Research conducted by Çeçen-Erouğul and Zengel that group experience based on the Assertive Training program can have a positive impact on adolescent Assertive levels which subsequently benefits when they are oppressed [20].

\section{CONCLUSION}

This study revealed a number of conclusions. The collaboration of Assertive Training and physical activity learning, as well as learning physical activity without Assertive Training was a predictor of Assertive behavior in deaf students at Citeureup Special School in Cimahi. Between these two learning, collaboration between Assertive Training learning and physical activity has the most influence in developing assertive behavior in deaf students. This means that the more often the learning is done, the more assertive behavior that the deaf students will be developed.

\section{REFERENCES}

[1] Y. R. Lin, I. S. Shiah, Y. C. Chang, T. J. Lai, K. Y. Wang and K. R. Chou, "Evaluation of an assertiveness training program on nursing and medical students' assertiveness, self-esteem, and interpersonal communication satisfaction," Nurse Education Today, vol. 24, pp. 656665, 2004.

[2] W. Banks, and Cindy Smith-fee "Middle School PE-Assertiveness Training." 3084 (June), 1989.

[3] P. G. Jacobs, Deafness-Specific Tactic Knowledge: A New Understanding of Mental Health, and Social and Professional Participation. Melbourne: Australia. ISBN 978-953-51-0269-4, 2012.

[4] M. Suarez, "Promoting social competency in deaf students: The effect of an intervention programme," Journal of Deaf Studies and Deaf Education, vol. 54, pp. 324-336, 2000.

[5] R. Alberti and M. Emmons, Your Perfect Right: Assertiveness and Equality in Your Life and Relationships (9th.ed). Atascadero, California: Impact Publisher, 2008.

[6] M. Efe, F. Öztürk, S. Koparan and Y. Şenişik, "Effect of volleyball studies on social competence expectations and assertiveness of men on age group of 14-16," Uludag University Journal of Faculty of Education, vol. 11, no. 1,pp. 69-77 (In Turkish), 2008.

[7] Y. Hutzler, A. C. Guber and Reiter, "Psychosocial Effects Of ReverseIntegrated Basketball Activity Compared To Separate And No Physical Activity In Young People With Physical Disability.,'Research In Developmental Disabilities vol. 34, pp. 579-587. University Of Haifa, Faculty Of Education, Israel, 2013.

[8] G. Tekin, M. T. Amman and A. Tekin, "The effect of recreational physical exercise on depression and assertiveness levels of university students," International Journal of Human Sciences, 2009.

[9] K. Yiğiter, I. Sari, Y. Ulusoy and F. Soyer, Examining the effect of recreational activities on university students' self-esteem. Sport Scientific and Practical Aspects, vol. 8, no. 2, pp. 15-19, 2011.

[10] J. G. Ryan and D. A. Dzewaltowski, Comparing the relationship between different types of self-efficacy and physical activity in youth Health Education and Behavior, vol. 29, pp. 491, 2002.

[11] R. L. Sanders, "Assertive Communication Skills With Nurses in a Rural Setting. Master' Thesis," The University of Wyoming. M. S. Whitney School of Nursing. Nurse Education in Practice, vol. 3, pp. 30-42, 2007. 
[12] K. Yiğiter, "Improving the Nursing Students' Assertiveness Skills by Participating in Recreational Physical Activities." Vol. 3, pp. 3, pp. 25862, 2013.

[13] I. Etikan, S. A. Musa, and R. S. Alkassim, "Comparison of Convenience Sampling and Purposive Sampling," American Journal of Theoretical and Applied Statistics, vol. 5, pp. 1-4, 2016.

[14] J. R. Fraenkel, N. E. Wellen and H. Hyun, How To Design And Evaluate Research In Education. New York: McGraw-Hill Inc, 2012.

[15] Avşar, Fatma, and Sultan Ayaz Alkaya, "The Effectiveness of Assertiveness Training for School-Aged Children on Bullying and Assertiveness Level.” Journal of Pediatric Nursing vol. 36, pp. 186-90, 2017.

[16] A. Nojedehi, M. T. Aghdasi and M. Shojaei, "The Effect of the Skill level, Sports Disciplines, and gender on Karatekas' assertiveness (Kata and Kumite ), vol. 5, no. 4, pp. 470-474, 2015.
[17] M. M. Meyer, "The effects of assertion training on assertive behaviors, self-acceptance, self-concept, and locus-of-control," Dissertation Abstracts International vol. 52, no.4- B, pp. 2331, 1991.

[18] E. G. Boket, M. Bahrami, L. Kolyaie and S. A. Hosseini, "The effect of assertiveness skills training on reduction of verbal victimization of high school students," International journal of humanities and cultural studies, August special issue, pp. 690 -699, 2016.

[19] Eslami, Ahmad Ali et al., "The Effectiveness of Assertiveness Training on the Levels of Stress, Anxiety, and Depression of High School Students." Iranian Red Crescent Medical Journal, vol. 18, no. 1, pp. 110, 2016.

[20] A. R. Çeçen-Erou ğul and M. Zengel, "The effectiveness of an assertiveness training programme on adolescents' assertiveness level. Elementary Education Online, vol. 8, pp. 485 -492, 2009. 